Int. J. Dev. Biol. 48: 497-508 (2004)

\title{
Brain tumour development and invasion An interview with Ole Didrik Laerum
}

\author{
DIETER F. HÜLSER* \\ Department of Biophysics, Institute of Biology, \\ University of Stuttgart, Germany
}

I know Ole Didrik Laerum since 1971 when we both worked as post-docs at the Max Planck Institute of Virus Research in Tübingen. We co-operated not only scientifically but also educationally when we hiked with our children through the Swabian Alb. Sometimes Ole had a hard time when his three sons wanted to be carried at the same time and I could not assist him because my two boys hang already round my neck. This did not discourage him, since more children followed and today he also cares for foster-children in Ethiopia.

Ole Didrik's scientific interests reach far beyond the subject of this interview and include topics such as chronobiology, aging and therapeutic aspects of different diseases and expand to profound contributions to the preservation of old Norwegian rural architecture and folk music. He actively plays several instruments and his good sense of humour can be judged from his contributions to the Journal of Irreproducible Results. When I mention that he was rector (elected president) of the University of Bergen for 6 years and organized numerous scientific conferences and workshops, then it is only to illustrate the problems of finding time and place for an interview with such an active personality. Thanks to telephone and e-mail connections these problems were solved without much delay.

Ole Didrik, your father and your grandfather worked as physicians in Voss (Norway) treating patients not only in town but also in a large rural area. The old family house is

now again your home where you preserve your ancestors' old instruments and appliances and collect related items. Obviously you are well embedded in your family's and country's heritage. Why did you not continue the family tradition as a physician but instead, escaped to science?

My main motive for studying medicine was an interest for general practice and for psychiatry, but on my way I stumbled literally. In the middle of my study I spent a semester as volunteer at the Pasteur Institute in Paris. After my return I had a ski accident and both legs were plastered. Thus, I had to continue my studies in a wheel chair for a couple of months and thereafter on crutches. During the summer I had to work some weeks at the Institute for Pathology at the National Hospital in Oslo under the supervision of Professor Leiv Kreyberg (1896-1984), since I had missed the microscopy course in pathology while I was hospitalized. His successor, then a post doc, Olav Hilmar Iversen (1923-1997) asked me to perform some experiments for him. Both of them were outstanding scientists and strong personalities - and very inspiring.

In the beginning, the project was not very successful, but we decided to continue in order to find out what was wrong. This led to several interesting findings about energy metabolism in precancerous epidermal cells and opened my eyes to the fascinating world of science. At the time when I graduated in 1965, I had my own tiny laboratory working besides the studies, and I decided to continue as a research fellow before I did my internship in other hospitals. Thus, the ski accident brought me to pathology and

*Address correspondence to: Prof. Dr. Dieter F. Hülser. Am Wildwechsel 2, D 70565 Stuttgart, Germany. e-mail: dieter.huelser@onlinehome.de 


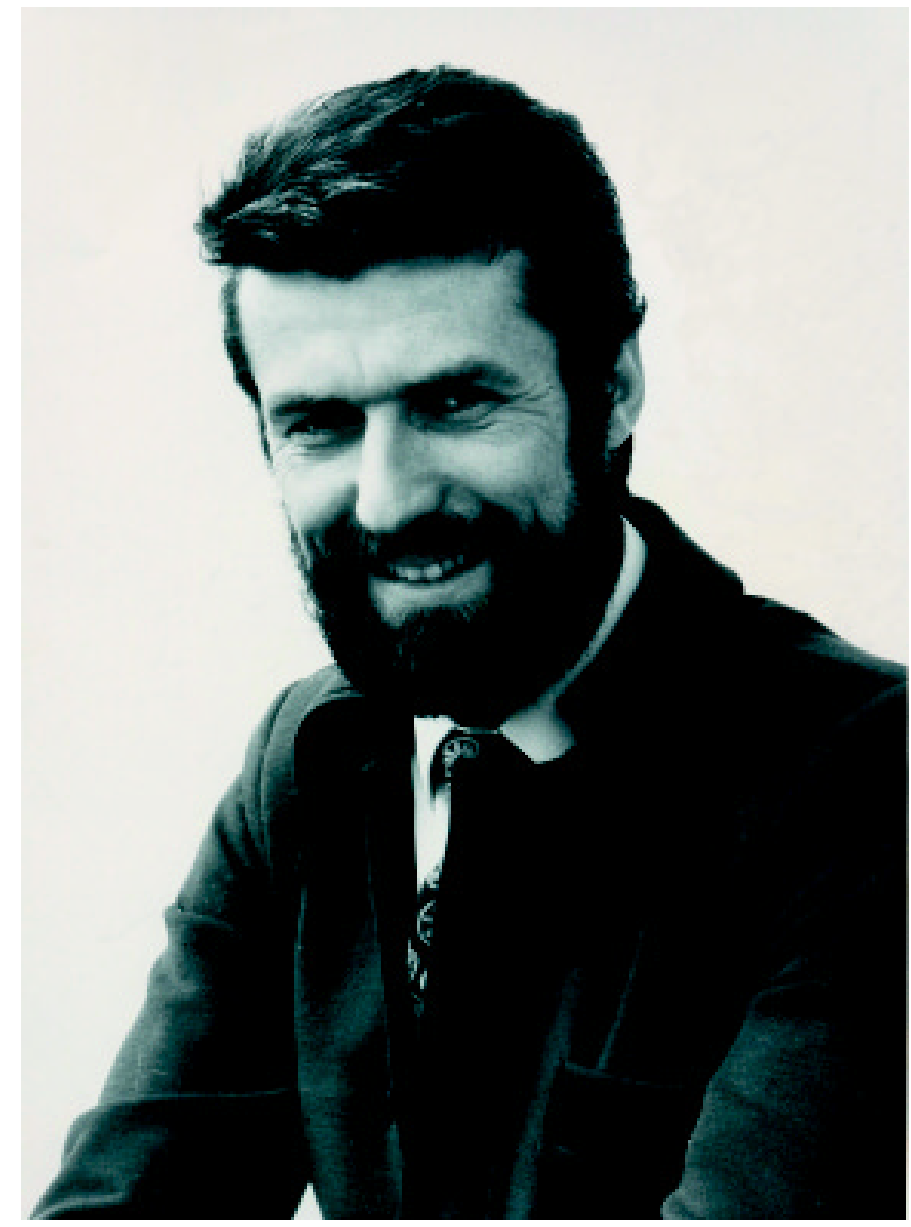

Ole Didrik Laerum as post-doc in Tübingen (1972).

cancer research where I have remained ever since. Maybe, I will do something else in my next life! Anyhow, my interest for the history of medicine and old medical instruments is my way to keep contact with the work of my forefathers.

When you started working in the field of carcinogenesis in brain, what was known about the induction of malignant transformation in nervous systems?

In the early 1970's much was known about chemical agents causing carcinogenesis in different organ systems, both in laboratory animals and man. Many chemical substances, most of them alkylating agents, were found to induce tumour formation in various organs, depending on the chemical structure and the susceptibility of the target tissue at the time of administration. After the research had been centred on carcinogenic hydrocarbons for several generations, $\mathrm{N}$-nitroso compounds were identified in the 1960's as cause of specific tumours in various target organs, and not least in the nervous system. This was an important break-through, since the possibility to study carcinogenesis in the brain and in the peripheral nervous system had so far been very limited. In particular, foetuses were susceptible to such carcinogens after systemic exposure, since their repair enzymes for alkylation damage are not yet transcribed.

Where did you acquire your expertise in carcinogenesis and what was your first major project in this field?
I did my PhD thesis on metabolic events related to cell population kinetics during the early stages of mouse skin carcinogenesis with O.H. Iversen in Oslo 1969. One result of this research was the first specific method for separating basal and differentiating cells from the mouse epidermis, a method that became widely used for flow cytometric studies of epidermal cells. The main finding of the carcinogenic studies was that reduced respiration and increased glycolysis in pre-cancerous skin both reflected altered cell population kinetics and carcinogenic damage.

Afterwards I came as post doc to join the group of Manfred Rajewsky at the Max Planck Institute of Virus Research in Tübingen, Germany, in 1971. At that time standardised systems which had been developed by Ivankovic, Druckrey and others gave the opportunity to specifically induce tumours in rats by administration of a pulse of ethylnitrosourea at the $18^{\text {th }}$ day of gestation. The mothers did not develop tumours, while more than 90 percent of the offspring got tumours of the brain after a mean period of about 7 months. Since very little was known about the cellular events taking place in the brain from the carcinogenic pulse until malignant growth, the goal now was to study these target cells directly in vitro. Such an approach had never been tried before, and it was considered as a high risk project since brain cells were extremely difficult to cultivate. In addition, there were generally very few reports about malignant transformation of normal cells in vitro after carcinogen exposure, with the exception of some pioneering experiments, including Charlie Heidelberger's studies on mouse fibroblasts from the prostatic gland.

You were successful in explanting foetal brain cells to cell culture. How soon could you detect indications of transformation in these cultured cells?

We could show that the target cells underwent stepwise transformation in vitro, whereby the cells exhibited sequential properties of malignancy. This included morphological transformation, accelerated growth, pile-up foci and loss of anchorage dependence. Finally, the cells were tumourigenic by re-transplantation into isogeneic hosts after 6-7 months. This was the same period as it took to develop tumours in vivo (Laerum and Rajewsky, 1975). In careful studies which were done by Peter Lantos and Geoffrey Pilkington in London, histological analysis of the treated brains showed similar stepwise alterations from clusters of glial cell proliferation, via tumour nodules to fully invasive malignant growth. Joan Roscoe at the Middlesex hospital could later show that brain cells explanted to in vitro conditions at longer intervals after carcinogenic treatment also underwent a similar transformation process.

\section{Which cell types were transformed?}

The phenotype of the malignant cells was mainly that of glial cells (Laerum, Hülser and Rajewsky, 1976; Laerum, Rajewsky, Schachner, Stavrou, Haglid and Haugen, 1977). However, electronmicroscopical and other phenotypic studies of the neoplastic cell lines indicated that also neuronal cells were involved in the malignant process (Haugen and Laerum, $1978 \mathrm{a}, \mathrm{b})$. Contrary to a common belief at that time, it could be shown that the malignant cells were electrically coupled, and not growing as independent single cells (Laerum, Hülser and Rajewsky, 1976).

I remember these experiments since I put much effort into quantifying the electrical coupling via gap junctions which led to "simple" input resistance measurements. None of the inves- 


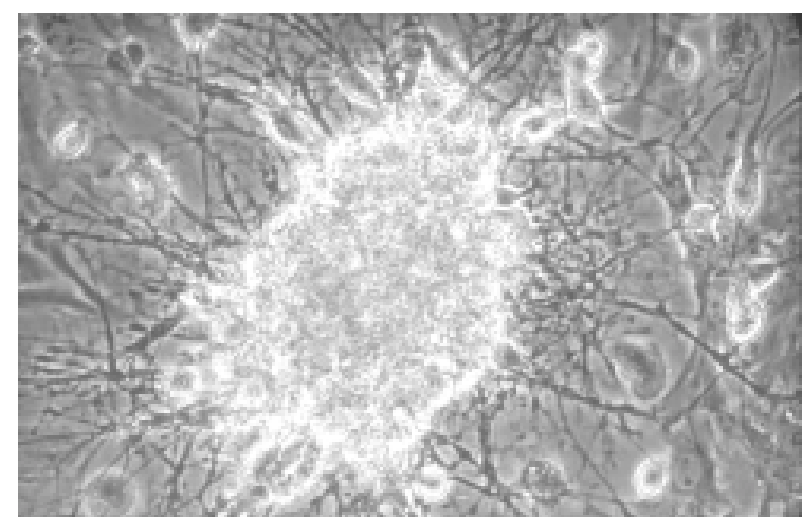

Fig. 1. Preneoplastic rat neural cells under malignant transformation in culture after carcinogen exposure in vivo. After 7 months these cells became tumourigenic and invasive (phase contrast). This work initiated Ole Didrik Laerum's research on carcinogenesis and tumour biology in the nervous system.

tigated 14 cell lines was excitable. Does it mean that nerve cells were not involved in the transformation process or that only glial cells survived in culture?

Further ultrastructural studies not only identified the neural origin of the neoplastic cells but also showed that they could be induced to differentiate into glial cells by various exogenous factors (Haugen and Laerum, 1978c). This meant that pre-neoplastic cells still had the ability to differentiate into glial cells. However, when they were fully malignant, their phenotype and ultrastructural morphology appeared to be more stable and less susceptible to exogenous factors (Haugen and Laerum, 1978d and 1979).

Did you find indications for excitable cells with potential- or ligand-dependent $\mathrm{Na}^{+}$channels?

Our studies and also the works of others indicated that this was the case and also that the transformed cells were precursor cells of the nervous system. Later, Stefan Patt and Helmut Kettenmann in Berlin could show in elegant studies that human glioblastoma cells are excitable and make action potentials. Thus, the malignant cells are able to develop into all lineages of neural cells.

\section{What was the impact of these findings?}

As a consequence, a large body of information now became available for the first time on how neural cells transformed into malignancy. In addition, their phenotypic properties were well characterised, and the different stages of carcinogenesis could be specifically studied. Furthermore, a series of malignant cell lines resulting from these experiments turned out to be heterogenic and exhibited various features of neural cells both in vitroand in vivoafter re-transplantation subcutaneously or intra-cerebrally into rats. This combined in vivo / in vitro approach was extremely valuable for further elucidation of tumour development and malignant features of cells from the nervous system.

These were preferentially investigations of phenotypic cell properties. Brain tumours are known to be invasive, how was this phenomenon studied?

In the 1930's the Belgian pathologist Hans Joachim Scherer performed a meticulous histological study on the growth of malig- nant brain tumours in humans. He described systematically how tumour cells invaded the adjacent brain tissue, following existing anatomical structures and taking shape after them, denoted secondary structures in contrast to the primary structure of the cells in the tumour itself. Later, it was fully recognised that invasiveness by malignant gliomas was the hallmark of their malignant potential, whereby most of the brain could be destroyed within a short time as seen with the highest grades, the glioblastomas. However, little was known about the biological features behind these processes (for review see Laerum, 1997 and Laerum and Mørk, 1998).

To correlate physiological properties with invasive behaviour different histological methods had to be developed.

During the 1970's, Marc Mareel and Leo de Ridder at the University of Ghent had developed organotypic methods for the study of invasiveness by malignant tumour cells in vitro. While monolayer cultures were not suited for such studies, they could show that different types of solid tissue fragments could be used as target for invasive cells when kept in gyratory shakers as organ culture. Different types of tissues had different permissiveness; alternatively some were more resistant to malignant invasion than others. Cartilage was resistant, while chick heart tissue was found to be well suited for invasion studies. On this they based a standardised organ culture model (Mareel, Klint and Meyvish, 1979). This model was now employed for the study of malignant transformation in the rat nervous system. In Leo de Ridder and our first publications in 1981 (de Ridder and Laerum, 1981) it was shown that pre-neoplastic and neoplastic neural cells from monolayer cultures could form aggregates in a gyratory shaker. When these aggregates were brought into contact and attached to fragments from 9-day embryonic chick hearts, a standardised system for the testing of invasiveness was obtained. Tumourigenic neural cell lines invaded the heart fragments as characterised by progressive replacement of heart cells by invading cells. The heart tissue degenerated irreversibly. Non-tumourigenic cell lines did not show invasiveness in vitro. Thus, in this co-culture system, invasiveness seemed to be a late event in malignant transformation and came simultaneously with tumourgenicity by re-transplantation (Laerum, Mørk and de Ridder, 1982, Laerum, Rajewsky and de Ridder, 1982, Mørk, de Ridder and Laerum, 1982).

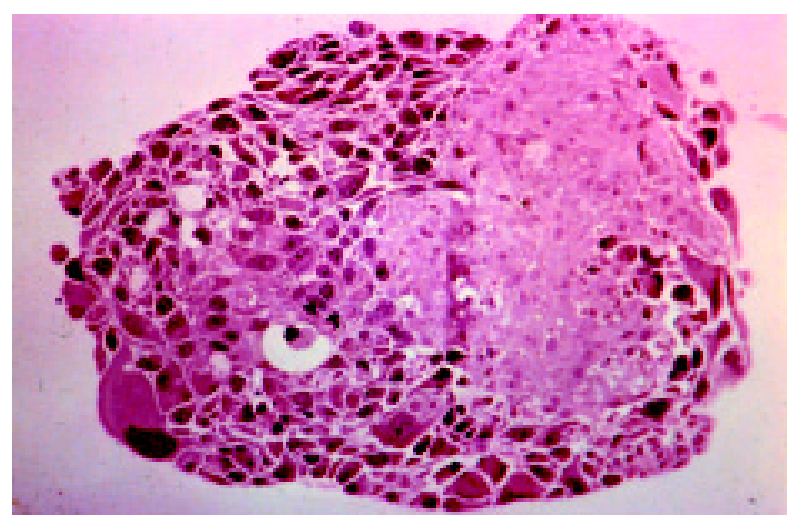

Fig. 2. Chick heart fragment invaded by rat glioma cells after 4 days of co-culture. Haematoxylin and eosin stain. From de Ridder and Laerum, (1981b). 
These experiments gave the impression that invasiveness is a general property of malignant cells irrespective of the target tissue.

Direct histological studies on pre-neoplastic neural cells in the rat brain done by Lantos and Pilkington indicated that from the very beginning these cells had a diffuse border to the normal tissue. In addition, the clinical experience indicated that at least the highest grade of glioma was invasive at a very early stage and long before clinical symptoms appear. Hence, the late occurrence of invasiveness into heart muscle might therefore be more related to their ability to degrade the muscular tissue with transcription of appropriate proteolytic enzymes, which might be different from the degrading process in the brain.

Later, we could show that invasiveness was a progressive and localised process in vitro, whereby cytoplasmic extensions from the malignant brain cells penetrated between the myocytes and gradually degraded the normal cells (Laerum, Mørk and de Ridder 1982, Mørk, Laerum and de Ridder 1983).

\section{But not all cells behaved similarly?}

It was evident that during malignant transformation of brain cells in vitro, highly heterogeneous cell lines resulted. This could be shown by phenotypic properties as well as by different types of ploidy and chromosomal composition (Laerum, Mørk, Rajewsky, Hansteen and Haugen 1983). Thus, by re-transplantation from in vitro culture to animals, malignant cells were often selected that were different from those prevailing in vitro (Laerum, Bjerkvig, Steinsvåg and de Ridder, 1984). This revealed that physiological and morphological transformation in vitronot always reflected the malignant cells which would dominate malignant progression in vivo. Evidently, other factors such as angiogenic capacity, apoptotic mechanisms and growth capability would also contribute as more or less independent factors.

\section{Can you give some examples?}

In the early 1980's it was evident that malignant brain tumours were able to break open adherent cell junctions of the host followed by gradual cell lysis and destruction of the normal cells. In vitro organ culture systems had then been made available for invasiveness studies, which to some extent reflected the same process in the brain. However, there were also differences, which

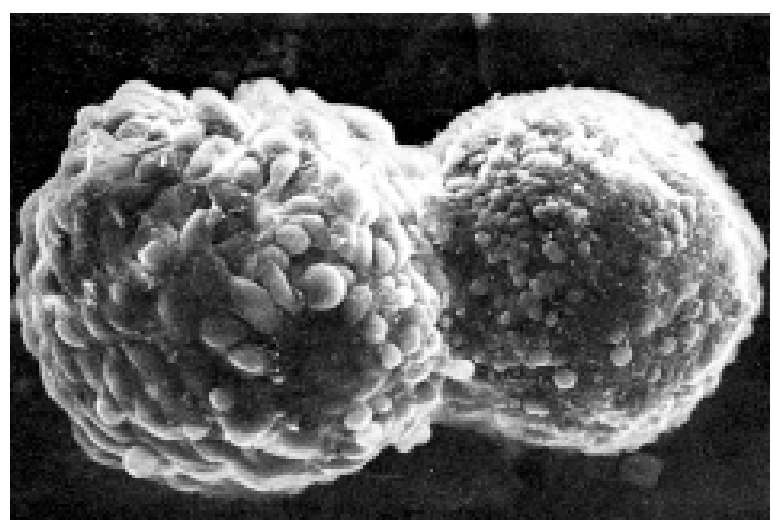

Fig. 3. Co-culture between foetal rat brain tissue (right) and glioma spheroid (left) after 24 hours. Scanning electron micrograph from Steinsvåg (1985). could be attributed to a use of target tissue of different tissue origin. Progressive invasiveness seemed to be a late event during neural carcinogenesis (Laerum, Mørk, and de Ridder, 1984; Mørk, Laerum and de Ridder, 1984).

Furthermore, in collaboration with D. Bigner at the Duke University, we could show that also cell lines from human anaplastic astrocytomas or glioblastoma multiforme were invasive into precultured chick heart fragments in vitro. The same cell lines were also tumourigenic to athymic mice in vivo. However, one of the lines was only tumourigenic at high cell numbers in athymic mice, and was scored as non-invasive in vitro. One cell line, on the other hand, was invasive but not tumourigenic in mice. Thus, tumourigenicity and invasiveness in these test systems might partly depend on different factors, although in the majority of cases there was a concordance (Bigner, Bjerkvig and Laerum, 1985)

Obviously some more hurdles had to be taken before a reliable invasiveness assay for brain tumours was on hand?

The possibility to study invasiveness of malignant brain tumours outside the body was from the very beginning an appealing challenge. The protected site of the central nervous system and its susceptibility to all types of damage by intervention had for years put restraints on the possibility to study malignant behaviour in situ. On the other hand, methods for culture of brain cells and tissue outside the body were scarce and limited by the vulnerability of brain cells, often leading to rapid deterioration of explanted cells. Furthermore, the existing culture systems were not suitable for studying the complex interactions between normal and malignant cells which already in the 1980's were known to occur in vivo.

By the mid 80's, already some promising achievements had been made. Glioma cells could be cultured as monolayers in vitro and different resulting cell lines had already been extensively studied. Furthermore, several investigations of neuronal- and glial-cells in vitroshowed the feasibility to study both morphological and electrophysiological properties in a direct manner. In addition, it was possible to make brain spheroids by re-aggregating brain cell suspensions to organoid nodules. These were already employed for neurobiological studies (review by Laerum, Steinsvåg and Bjerkvig, 1985).

\section{These models are still far away from the complex structure} of a brain tissue!

Right. From these limited methods it was a big gap to complex studies of interactions between normal and malignant neural cells outside the body. This stimulated us to launch a research program with systematic development of models for such studies. A great inspiration was given by the already mentioned successful rat model where stepwise malignant transformation in foetal rat brain cells occurred in the same time frame as following the same carcinogenic treatment and subsequent observation in vivo. A great advantage was given by the availability of multiple differentiation markers which were altered during transformation (Laerum, Mørk, Haugen, Bock, Rosengren and Haglid, 1985).

\section{But invasion usually occurs in adult brain.}

Yes, as target tissue, adult brain tissue would have been ideal. Since the only available model were thin brain slices, 
which could be maintained for a short period under high oxygenation, it was instead decided to concentrate on the foetal rat brain taken at the $18^{\text {th }}$ day of gestation. These neural cells were known to grow readily in monolayer culture for a couple of passages. In a first approach two organ culture systems were developed: Solid tissue explants from foetal rat brain hemispheres, which rounded up and formed spheroids in a few days and could be kept for at least a month in suspension culture (Steinsvåg and Laerum, 1985), and disaggregating foetal rat brains into single cells suspensions, followed by aggregation to organoid nodules which could be further propagated for 1-2 months in microwell chambers as single organoid nodules (Bjerkvig, Steinsvåg and Laerum, 1986).

Re-aggregated nodules may contain much more connective tissue than solid explants. Did you see differences in these two systems?

Not in our hands, since both systems have the ultrastructural characteristics of the immature brain. However, the glioma cells themselves may be able to produce new extracellular matrix, including collagen, and normal brain cells may do the same when they are invaded.

Basically, our contribution was then to modify and standardise 3D culture systems so that they could be used for studies on normal and malignant tissues as well as for their mutual interactions (Steinsvåg, Laerum and Bjerkvig, 1985; Bjerkvig, Laerum and Mella, 1986). This means that the invasive process into the natural target tissue could be studied directly outside the body.

Tumour cells have also to be cultivated accordingly when their invasiveness should be studied in vitro.

Therefore the second part of our approach was to make similar modification of culture methods for malignant brain tumour cells, which could be directly compared. This was also successful with the cultivation of three-dimensionally growing spheroids of malignant brain tumour cells obtained from suspensions of either rat or human glioma cell lines, primary tumour cell suspensions, and solid explants of tumours taken directly from biopsies of patients (de Ridder, Laerum, Mørk and Bigner, 1987; Bjerkvig, Tønnesen, Laerum and Backlund, 1990). Such spheroids could be maintained for several months and were also transferred to monolayer cultures by letting them adhere to the substratum and grow out in all directions. At the same time, this re-explantation could be quantified and used as a measure for tumour cell migration in vitrounder standardised conditions (Bjerkvig, Laerum, and Mella, 1986). In addition, the genotype and phenotype of the invasive cells were well characterized (Bigner, Bjerkvig, Laerum, Muhlbaier and Bigner, 1987; Bjerkvig, Laerum and Rucklidge, 1989).

Were special culture conditions necessary to keep spheroids for such a long time?

A prerequisite of all these culture types, both normal and malignant was that they were kept as a stationary culture, thus avoiding any intervention with mechanical forces by shaking of gyratory rotation. This was obtained by covering the culture dishes or microwells with semisolid agar, which prevented adhesion of the cells, instead they adhered to each other and formed aggregates (Bjerkvig, Steinsvåg and Laerum, 1986).

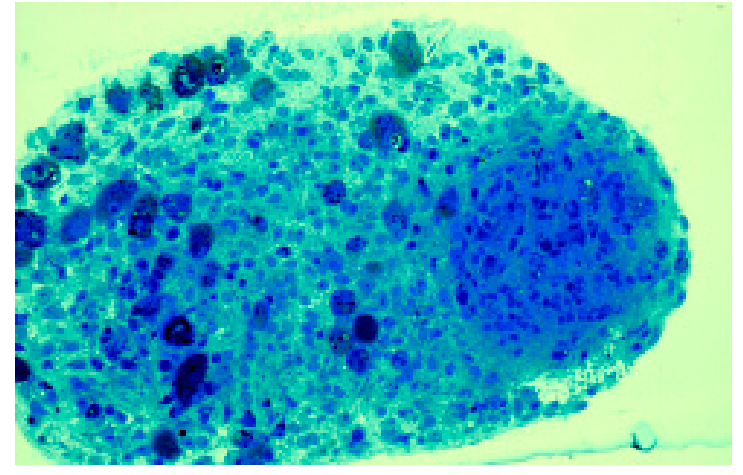

Fig. 4. Human astrocytoma cells (left) replacing re-aggregated brain tissue (right) after $\mathbf{4}$ days of confrontation culture. From Bjerkvig, Tønnesen, Laerum and Backlund, (1990).

Alternatively, solid explants remained in suspension and rounded up to a spheroid (Steinsvåg, and Laerum, 1985).

\section{What was the size of these spheroids before necrosis was observed?}

Within a culture period of 4 weeks we see the same limitations as for other types of spheroid culture: there is an upper diameter of about 0.4 millimeter. Beyond this size central necrosis develops.

\section{Did both types of spheroids - aggregates and explants - represent brain tumours?}

Extensive studies were done on the identification of the complex cell populations which formed such spheroids, both normal and malignant populations of neural origin. The main histological types of malignant brain tumours could be propagated in this way, including astrocytomas, oligodendrogliomas, glioblastomas, malignant schwannomas and medulla- blastomas, both from rats and humans (Mørk, de Ridder and Laerum, 1982; Bjerkvig, Tønnesen, Laerum and Backlund, 1990). Interestingly, solid tumour explants as spheroids would retain their histological characteristics as for example glioblastomas or malignant schwannomas in vitro, and the same also occurred for re-aggregated spheroids. However, with so small pieces of tumour tissue, biological characterisation is more reliable than histology.

With such a broad spectrum of culture methods, specifically directed to different histological types and neural cell populations, including different modification of media, a potent tool for the study of invasiveness into brain tissue in vivowas available.

When you confronted normal and malignant spheroids, did tumour cells migrate and encapsulate the normal spheroid before invasion started or did this occur preferentially at the contact site? In other words: how big is the invasion front?

After confrontation between tumour tissue or re-aggregated spheroids and foetal rat brain tissue or aggregates, in all cases the two types of spheroids were attached to each other. This was followed by malignant cell migration on the normal tissue surface, and thereafter a gradual replacement and destruction of the normal tissue. This occurred as a progressive process 


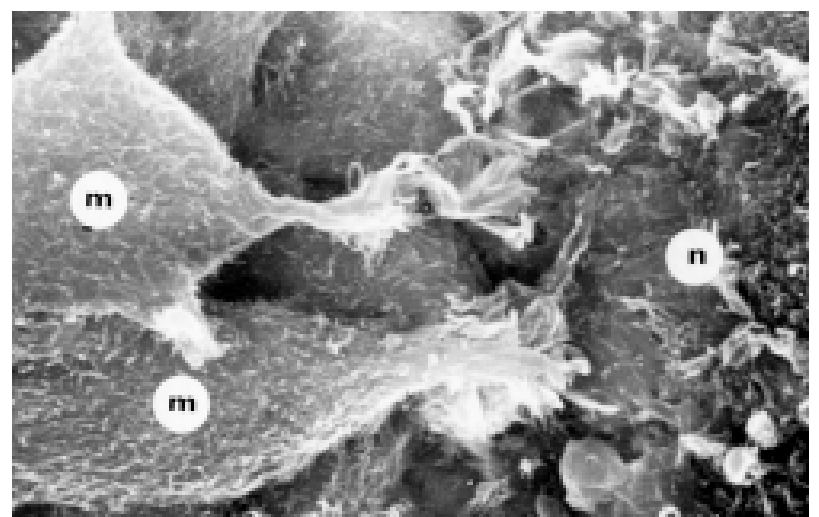

Fig. 5 (Left). Migration of glioma cells. Leading lamellae $(m)$ in the border area between a tumour aggregate and a normal brain solid fragment (n) after 3 days of co-culture. Scanning electron micrograph from Steinsvåg, (1985).

Fig. 6 (Right). Contact zone between malignant cell $(\mathrm{m})$ and the surface of a normal brain fragment. Scanning electron micrograph from Steinsvåg, (1985).

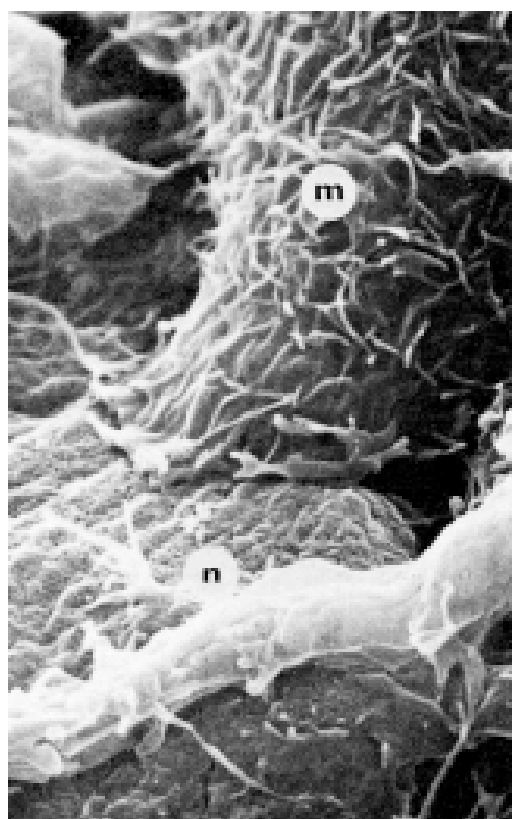

spheroids from tumour biopsies were also gradually replacing the normal aggregates, indicating that single cells readily migrated out from solid tumour tissue (Laerum and Bjerkvig 1990).

Do different tumour types behave differently?

Different histological types of human gliomas not only retained their histological picture as spheroids but also showed different pattern of replacement of the normal tissue. The tumour types included astrocytomas, mixed gliomas, ependymomas and glioblastomas as well as medulloblastomas (Engebraaten, Bjerkvig, Lund-Johansen, Wester, Pedersen, Mørk, Backlund, and Laerum, 1990; Terzis, Arnold, Laerum and Bjerkvig, 1994). ending with completely destroyed aggregates within 10 days of co-culturing. There were two main types of invasion, either as single cells, or as solid invasion with larger groups of cells. At the borderline between normal and malignant cells, there was a gradual lysis of the normal cells, while the malignant cells were intact. Normal cell junctions were split, and there was often a normal cell lysis far away from the invasion sound. At the end of this process, a small core of normal tissue sometimes remained in the middle of the malignant cells (Steinsvåg and Laerum 1985a).

How could you discriminate normal from malignant cells in your histological sections?

This has been done with many different methods. LacZ labelling of the invading cells is one possibility, immunostaining with different specific antibodies is another. The normal and malignant cells can also be vitally stained with different fluorochromes before confrontation. Then the sequence of malignant invasion can be studied as a stepwise process and quantified from day to day with confocal microscopy.

In order to see if this really represented progressive invasion, tests were done with confrontation between similar types of spheroids. Normal cell brain aggregates would rapidly fuse when brought together, making one larger aggregate. Malignant cell aggregates would do the same. However, when one normal aggregate was confronted with a malignant one, progressive destruction of the former resulted. In addition, since the normal brain aggregates were organised into a zone with glial cells, neuronal cells and neurophil in a structured fashion, it could be observed from day to day how one layer after the other was destroyed and replaced by malignant cells.

Are spheroids of normal brain tissue similarly organized and did you observe the same invasion pattern?

Yes, a further proof was that solid brain tissue was destroyed in the same way as re-aggregated normal brain cultures. Similarly, solid
Could you identify physiological properties of invasive glioma cells which had not been detected in vitro?

With progressive invasive behaviour in vitro, several biological properties were identified in malignant cells, which otherwise would not have been observable in vivo. Already in vivo it had been noted that extensive destruction of the normal brain tissue might be seen adjacent to an invasive brain tumour. In vitro, lysis of normal neural cells could be seen at long distances from the invasion zone.

Later this was identified to be due to different types of proteolytic enzymes, mainly metalloproteinases and also urokinase which could be secreted into the extracellular space. In addition, invading tumour cells often contained remnants of normal cells. Using a standardised flow cytometric method, where cells are allowed to ingest fluorescently labelled material, this was further addressed. We could show that malignant glioma cells rapidly phagocytosed bacteria, zymosan particles, erythrocytes and cell remnants (Bjerknes, Bjerkvig, and Laerum, 1987). Since normal astrocytes also had a high phagocytotic capacity, this was not a specific property of the malignant cells alone. However, in connection with invasion, they seemed to be particularly active. At that time, it was a surprise that both astrocytes and glioma cells were active phagocytes, since this had so far been mainly attributed to microglial cells in the nervous system.

Proteolytic enzymes must be present in a high concentration to induce lysis of intact cells at contact sites. But with spheroids a special problem is apparent and this is necrosis due to a limited supply with metabolites in the inner zone. This would rather lead to a passive replacement of normal tissue by tumour cells instead of an invasion of tumour cells in between normal tissue. Does the word "invasion" purport both processes?

I agree that this can be a limitation unless strictly standardised conditions are used and the findings are reproduced with different types of tumour cells and normal target tissues. This has also been addressed in extensive studies. 

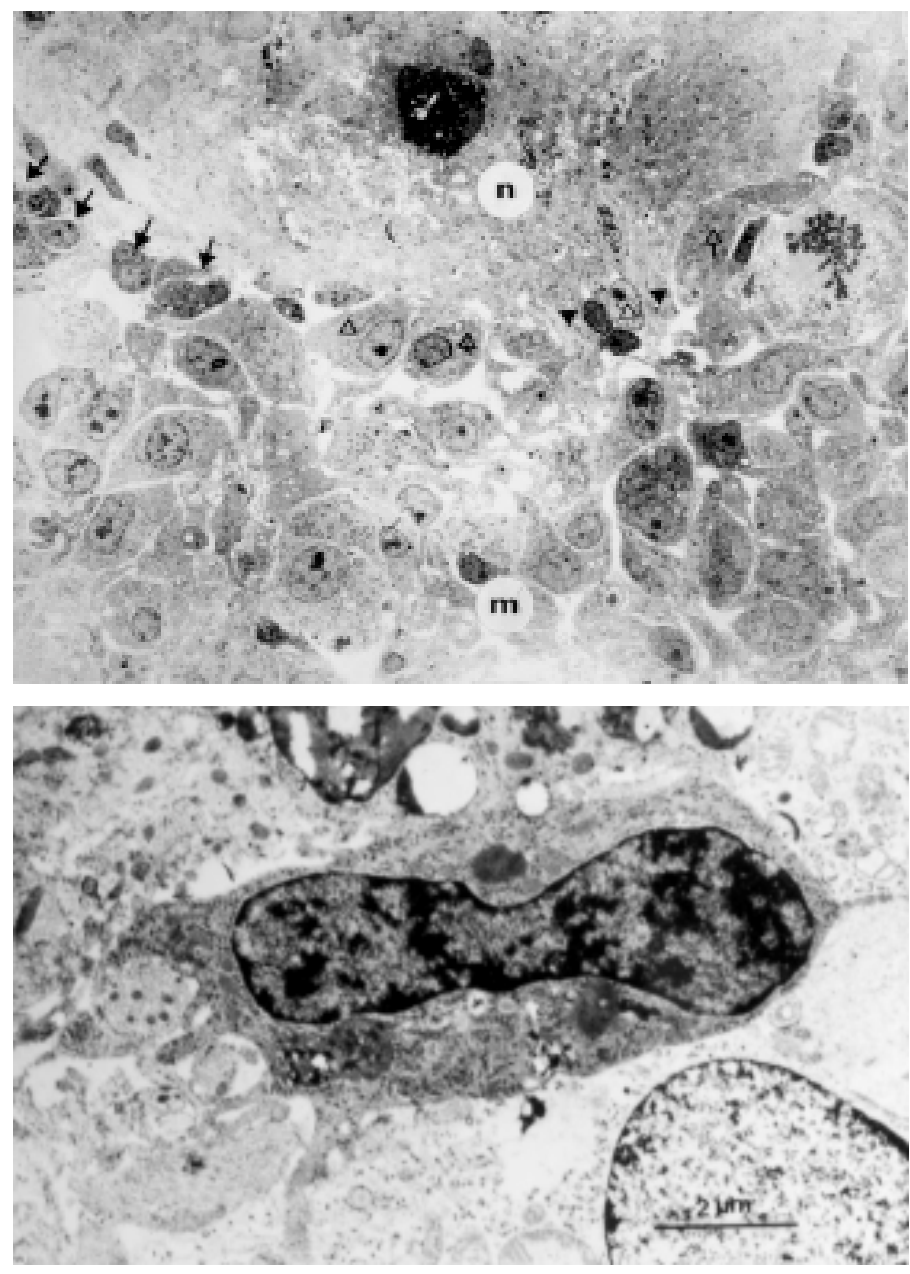

Fig. 7 (Top). Confrontation zone between normal brain tissue (n) and glioma spheroid $(\mathbf{m})$ after $\mathbf{3}$ days of co-culture. Arrows on the left: remnants of the peripheral glial layer. Black triangles on the right: glioma cells invading the neurophil layer. Far right: a mitotic tumour cell. Transmission electron micrograph from Steinsvåg and Laerum, (1985).

Fig. 8 (Bottom). Glioma cell in the middle of brain tissue. Transmission electron micrograph from Bjerkvig, Laerum and Mella, (1986).

Interestingly, while glioma spheroids are able to rapidly degrade normal foetal brain aggregates in organ culture, they are not able to do the same with aggregates of human leptomeningial cells (Pedersen, Rucklidge, Mørk, Terzis, Engebraaten, LundJohansen, Backlund, Laerum and Bjerkvig, 1994)). This can be one of the explanations why gliomas mainly invade in the brain and rarely metastasize outside the intracranial cavity.

Careful ultrastructural analysis of the invasion zone revealed close interactions between normal and malignant cells. Thus, tight junctions were formed, and in addition there was evidence that they were directly communicating via gap junctions (Steinsvåg and Laerum, 1985). This was in line with the earlier observation that the glioma cells were electrically coupled to each other in vitro. Now, normal and malignant cells might do the same, although this would lead to the ultimate death of the normal cells. Possibly, normal "behaviour" of malignant cells by such interactions could be one of the mechanisms for cell destruction during invasion.
It certainly helps malignant cells to survive and proliferate within normal tissue when they are metabolically coupled to normal cells. These aspects are always missing when noncellular assays are used to study invasion.

For several years multicellular assays were the main model systems for biological studies not only for brain tumour invasiveness in vitro. Less laborious methods were later developed by other workers in order to use them for large scale testing. This included assays as brain slices techniques, and monolayer cells for careful in vitro analysis of different cell functions related to invasiveness, including migration on different types of substrates, proliferation and degradation of different types of biological materials. Extracellular matrix in a modified version used as support for invasive cells also seems to discriminate between those malignant cells which penetrated this material and those who did not. Such matrigel assays could therefore give a rapid indication of whether cells were invasive or not, and in addition the ability of the cells to degrade the ECM was part of the assay.

However, this is far from the delicacy and complexity of the normal brain tissue, necessitating in vivo confirmation of the results. Unfortunately, the word invasiveness has been extensively used for the observations of malignant cells penetrating artificial substrates like matrigel, although all such in vitroassays only partly reflect the complexity of the in vivo situation. In my opinion the word invasiveness is being used too broadly today. Instead, in vitro studies on artificial substrates should rather be described as invasiveness-related phenomena.

Together with an American group we published a monograph on brain tumour invasion in 1998, which was the first of its kind in the literature. Here, all the available invasiveness assays were described together with available biological data on invasion as a biological process (Mikkelsen, Bjerkvig, Laerum and Rosenblum, 1998).

\section{Which are the methods that allow investigations of sequen-} tial processes during invasion?

Invasion and progression of malignant brain tumours in situ follow a relatively constant pattern and time course. With the most malignant type, the glioblastomas, mean survival is usually somewhat more than one year, and the disease is almost invariably lethal. This might give the impression that the biological processes involved in tumour disease are out of control but still follow a constant pattern.

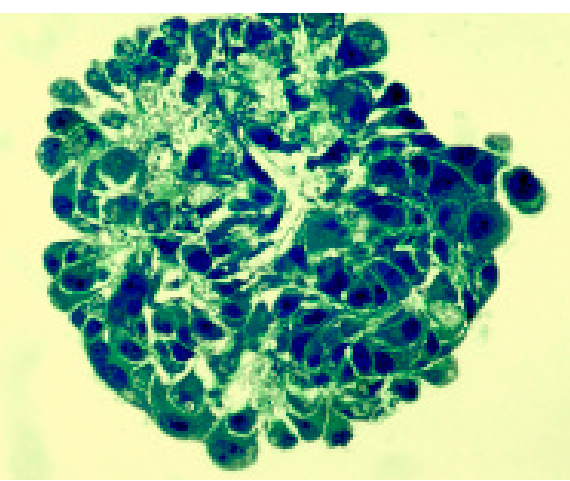

Fig. 9. Spheroid of rat glioma with intracellular zymosan particles. This indicates active phagocytosis of the malignant cells. From Bjerknes, Bjerkvig and Laerum, (1987). 


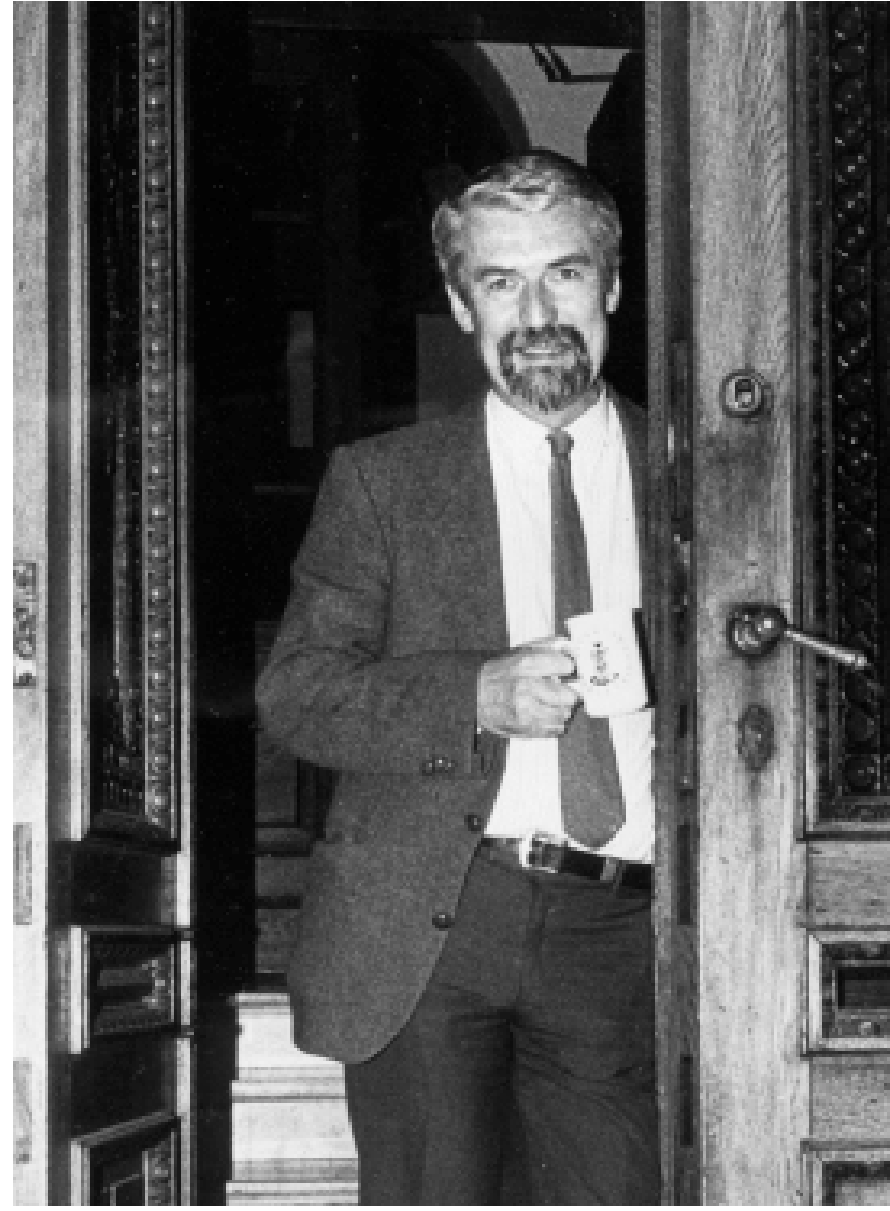

Ole Didrik Laerum wishing students welcome to the University of Bergen, (1992).

This view was challenged by our investigations on brain tumour invasiveness in vitro. Firstly, we designed methods to quantitatively measure invasion as destruction and replacement of the normal tissue. In the beginning we used morphometric methods, which were relatively laborious. This was followed by confocal laser scanning microscopy methods. In this case, the normal tissue and the malignant cells were labelled with two fluorescent vital dyes before confrontation. Thus, normal and free conditions, addition of serum generally accelerated the process. However, the greatest difference is seen between monolayer and three-dimensional culture, indicating that the latter by far provide the most similar conditions with in vivo growth (Ness, Pedersen, Bjerkvig, Laerum and Lillehaug, 1994). In particular, great care should be taken to ensure that the conditions can be compared to the in vivosituation when target test systems based on ECM proteins such as matrigel are used.

\section{Could you modify the invasiveness by addition of growth factors?}

Invasiveness could also be modified by biological regulators. Both in glioma cell lines and primary biopsy spheroids from tumours the rate of invasion varied considerably with the presence of growth factor receptors. Thus, addition of growth factors as EGF, PDGF, FGF and others could stimulate invasion directly in vitro, both on tumour spheroids and solid explants from glioma biopsies. The strongest effect was seen with EGF, although FGF and PDGF were also active (Lund-Johansen, Bjerkvig, Humphrey, Bigner, Bigner and Laerum, 1990; Lund-Johansen, Engebraaten, Bjerkvig and Laerum, 1990; Engebraaten, Bjerkvig, Pedersen, and Laerum, 1993). Later, other workers showed that HGF (scatter factor) greatly stimulated tumour migration. In our cases, both tumour cell migration and replacement of the normal tissue were stimulated by EGF. This could be retarded or even blocked by addition of blocking antibodies to the EGF receptor (Lund-Johansen, Bjerkvig, Humphrey, Bigner, Bigner and Laerum, 1990). However, it should be noted that the response may be quite heterogeneous in glioma cells from primary biopsies, indicating that these tumours consist of rather complex malignant populations (Pedersen, Ness, Engebraaten, Bjerkvig, Lillehaug and Laerum, 1994)

\section{Was one type of tumour stimulated by all growth factors or were individual tumours sensitive to different factors?}

Some cell lines were stimulated by EGF, while others were not, and some lines were inhibited by the antibody to the receptor, while others were not. This is well in line with the finding that a mutant EGF receptor may not be dependent on its ligand (LundJohansen, Bjerkvig, Humphrey, Bigner, Bigner and Laerum, 1990; Humphrey, Gangarosa, Wong, Archer, Lund-Johansen, Bjerkvig, Laerum, Friedman and Bigner, 1991). Also cell growth and migration were stimulated in the malignant spheroids, showing that EGF had several different effects on malignant cell functions (for review see Bjerkvig, Høstmark, Pedersen and Laerum 1991a). malignant cells could easily be discriminated from each other and the invasion rate was measured quantitatively over a period of up to ten days. The result was that the rate of invasion varied considerably with the individual tumours, as tested with spheroids from primary brain tumour biopsies (Nygaard, Haugland, Laerum, Lund-Johansen, Bjerkvig and Tysnes, 1998).

\section{Did you also observe variations due to culture conditions?}

Interestingly, in vitro invasiveness was to a certain degree dependent on the culture medium. Although the process could also occur under serum
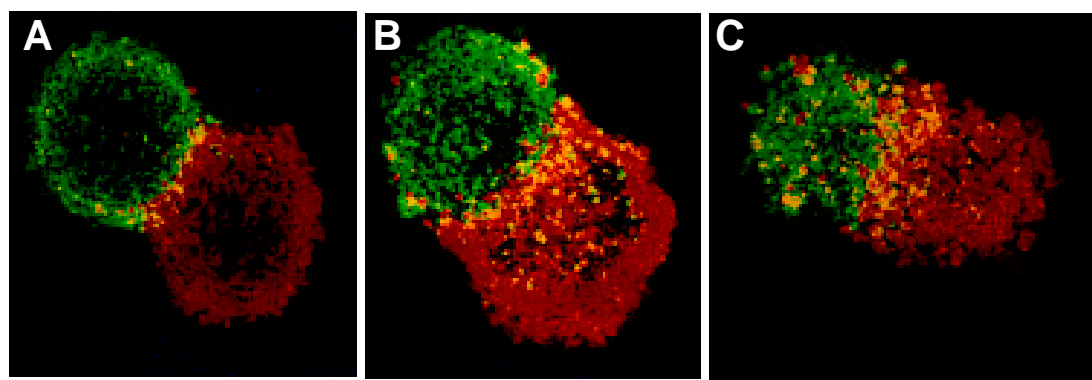

Fig. 10. Sequence of replacement of brain cell aggregate by human glioblastoma tissue from primary biopsy. (A) $24 h$, (B) $48 h$ and (C) $96 h$ of confrontation culture. Confocal scanning micrograph of vitally stained tissue; green, brain aggregate; red, tumour tissue. From Nygaard, Haugland, Laerum, Lund-Johansen, Bjerkvig and Tysnes, (1998). 


\section{Curriculum vitae \\ Ole Didrik Laerum \\ 1940 Born in Voss, Norway \\ 1965 M.D. University of Oslo \\ 1969 Ph.D. University of Oslo \\ Internship, 6 months general practice, training in pa- thology \\ 1971-73 Post doc at Max Planck Institute for Virus Research, Tübingen, Germany \\ 1974 Associate professor \\ 1980 Full professor of experimental pathology and oncol- ogy, University of Bergen (The Gade Institute). \\ 1984-89 Vice rector and \\ 1990-95 Rector (President) of University of Bergen, Norway. \\ 1992-94 Chairman of the board of the Research Council of Norway. \\ 1996 Visiting professor at IACR, Lyon \\ 1997 Visiting professor of molecular biotechnology, Univer- sity of Washington, Seattle.}

Does this mean that you can accelerate the process of invasion by appropriate combination of growth factors and metabolites?

Yes, progressive invasion into brain tissue in vitrois not a constant process, but may be greatly modified by biological regulators. Furthermore, we have recently found indications that foetal rat brain tissue is particularly permissive to malignant glioma invasion (Laerum, Nygaard, Steine, Mørk, Engebraaten, Peraud, Kleihues and Ohgaki, 2001). Thus, the degree of invasion in vitro is far higher than would be expected for the dynamics of clinically observed tumour spread. This suggests that mechanisms suppressing invasion may be operative in the normal brain; alternatively the difference may be due to a higher permissiveness of the foetal brain tissue for invasion in vitro. The advantage with a high permissiveness is that progressive invasion can be observed and quantified within a relatively short time, which usually implies one week. This is greatly different from the in vivo conditions where such quantitative data have only been obtained indirectly, either by clinical observations or by radiographic methods in sequence over months.

Accelerated in vitro processes may allow a better prognosis when biopsies of brain tumours are available. But your data also point towards therapy: do you think new approaches for growth inhibition or retardation of tumours will be possible in the near future?

Indeed, when stimulation of invasiveness is possible in vitro, retardation or even blockage should also be possible. As already mentioned, antibodies to EGF are to some extent capable of this. In addition, spheroids of human glioma cells that express high levels of GM2 ganglioside will undergo necrosis when exposed to specific antibodies (Bjerkvig, Engebraaten, Laerum, Fredman, Svennerholm, Vrionis, Wikstrand, and Bigner, 1991b). Based on our work, several treatment modalities were applied for retarding or stopping invasion in the systems in vitro, such as single doses of irradiation, alkyl-lysophospholipid, microtubule inhibitors as vincristine, also in combination with phenytoin and others (Engebraaten, Schwachenwald, Valen, Bjerkvig, Laerum and Backlund, 1992; Tysnes and Laerum, 1993; Nygaard, Laerum and Tysnes, 1994; Tonn, Haugland, Saraste, Roosen, and Laerum,

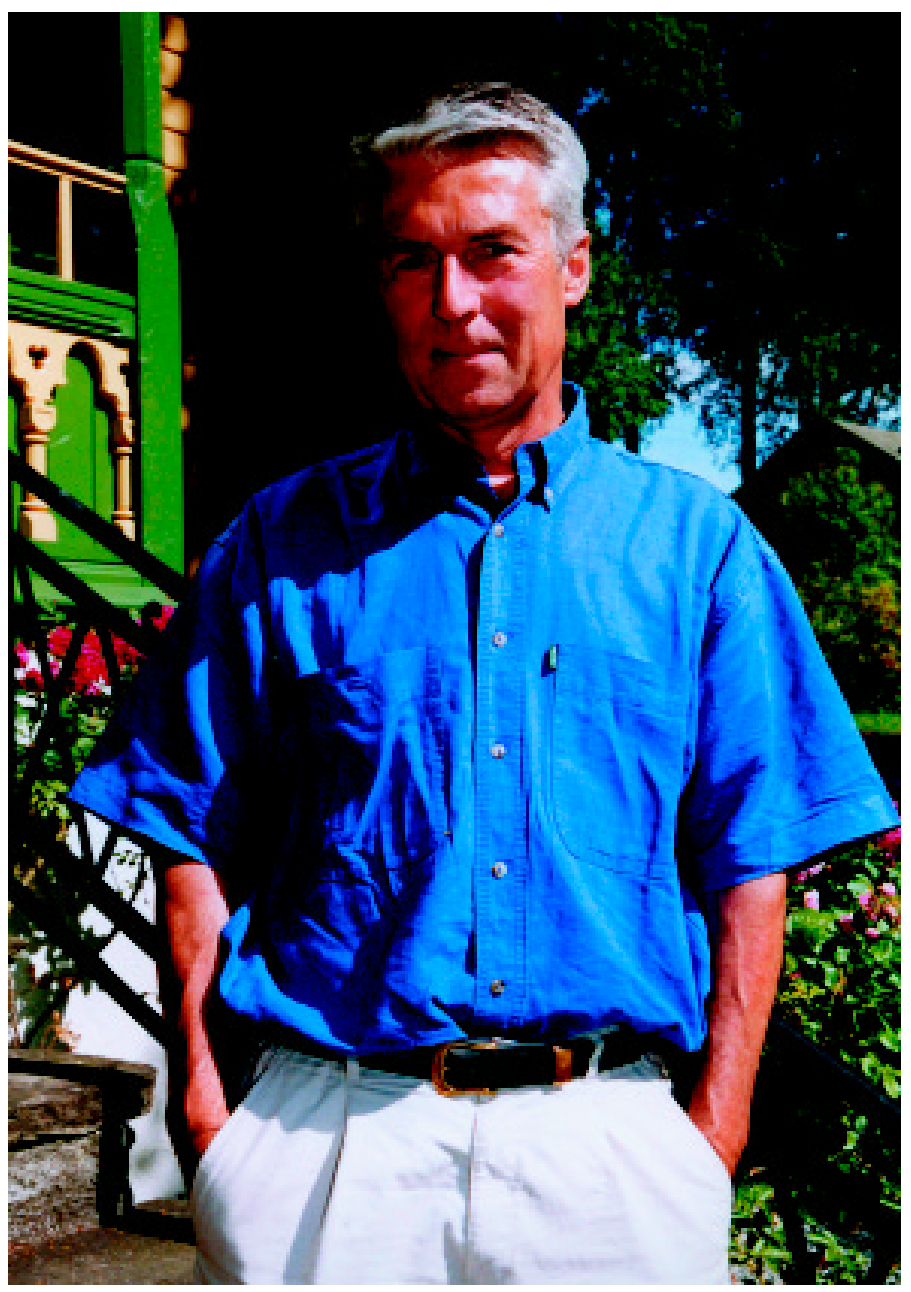

Ole Didrik Laerum at home (1998).

1995). In addition, the rat model makes it possible to construct in vivomodels for experimental therapy to be used in parallel with in vitro invasion assays as we have already shown in 1990 (Mella, Bjerkvig, Schem, Dahl and Laerum, 1990). Later, Rolf Bjerkvig and his group employed transplantation to immuno-deficient rats for studying malignant glioma cell migration and invasion, including human tumours. This also includes the identification of tumour stem cells.

However, the optimistic view that prevailed 10 years ago about possible anti-invasive therapy in brain tumour patients has not been confirmed so far.

\section{Do you think stem cells which are primed for malignant} growth really exist?

Recently, several workers have shown that malignant brain tumours contain primitive, transformed cells with properties similar to those of normal neural stem cells.

\section{When you mention stem cells then you should also comment} on normal migration of cells.

Invasiveness per se is not only a property of malignancy. Foetal brain cells are capable of extensive migration to other sites in the 


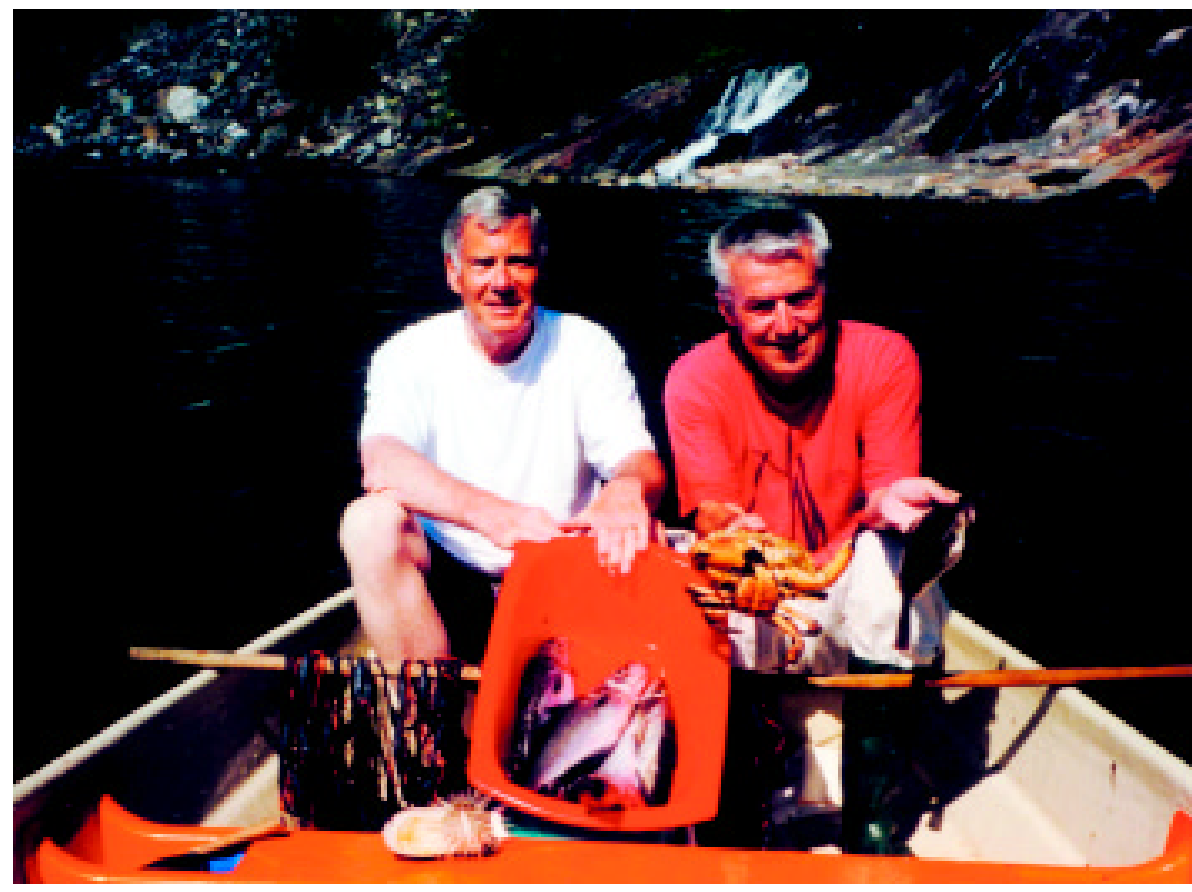

Ole Didrik Laerum (right) and Dieter Hülser (left) with their catch of the day out of the Hardanger Fjord (July, 2002).

brain during development. Using fluorescently labelled foetal cells, their migration inside the adult brain of rats can be followed after transplantation in the cerebrospinal fluid and when migrating along different structures into the brain. However, these cells do not cause progressive destruction, but more or less fuse with the normal structures (Marienhagen, Pedersen, Terzis, Laerum and Bjerkvig, 1994)). Our own studies indicate that surface molecules of the malignant cells, such as NCAM expression and Annexin II as well as different integrins are important for migratory and invasive properties. Thus, overexpression of NCAM may reduce invasiveness (Andersson, Moran, Gaardsvoll, Linnemann, Bjerkvig, Laerum and Bock, 1991; Edvardsen, Pedersen, Bjerkvig, Hermann, Zeuthen, Laerum, Walsh and Bock, 1994; Nygaard, Haugland, Kristoffersen, Lund-Johansen, Laerum and Tysnes, 1998). In addition, interactions with the extracellular matrix are of great importance. When a suitable matrix is not available, the invasive cells may also produce their own ECM, which supports further migration into the normal tissue. Different parts of ECM as well as integrins may be of importance, depending on the individual tumour and histological type (for review see Laerum and Mørk, 1998; Laerum and Rosenblum, 1998).

Together with others you have collected a lot of pieces of the still unfinished puzzle of invasion. Is it too early to formulate an orchestrating hypothesis of the invasion mechanism?

A constant pattern for a classification whether a tumour is highly invasive or not has not been found. It seems to be a combination of aberrant normal functions that constitute the phenotype. In later studies, Bjerkvig's group found evidence that angiogenesis may be a contributory factor for clinical malignancy of brain tumours. Recently, such tissue-specific organo-typic models, have been extended to bronchial carcinoma invasion into normal human bronchial mucosa (Fjellbirkeland, Bjerkvig, Steinsvåg and Laerum, 1996;
Fjellbirkeland, Bjerkvig and Laerum, 1998a; Fjellbirkeland, Laerum and Bjerkvig, 1998b).

Thus, multiple normal cell functions regulated in an abnormal way, ranging from migratory ability to cell surface properties and interactions with the extracellular matrix, as well as the ability to secrete ECM degrading enzymes, may act in concert with growth factors and their receptors as important modifiers. The lack of a single mechanism for invasive capability so far limits the possibility for a specific anti-invasive monotherapy.

Would you encourage young students to enter this field of investigations or do you think the concerted actions behind the invasive processes will be fully understood in the near future?

Invasiveness still represents a challenge in brain tumour research, both from a biological and from a clinical point of view. However, the possibility to study all aspects of this process outside the body and then compare them with the intercerebral phenomena in brain tumour disease has shed new light on mechanisms involved. Thus, a fairly good overview of biological phenomena taking place has been obtained, although the solution of many fundamental questions still remains in darkness. For young students who wish to enter the field of tumour biology and mechanisms of invasion, the combination of these approaches with cell and molecular biology offers unique possibilities for the exploration of underlying mechanisms. Yes, I would strongly recommend them to become involved.

We have learned that migration and invasion are also necessary events in normal development. I think similar nondestructive processes can also be observed in our society and in scientific communities. Many students participated in your work, proceeded and later launched their own groups. Recent publications reveal your ongoing partnership with these colleagues. As a grandfather of ten grandchildren, how do you like the feeling of being scientifically centred in a circle of actively cooperating rising generations?

Research is a continuous process where each worker makes his own data available for the scientific community with open dissemination of knowledge. It is also the promotion of new people to science. Some of the most stimulating work I have been involved in is the process of recruitment, by now a total of about 40 Ph.D. theses under my supervision, either alone or together with other colleagues. This has both been important for establishing scientific networks and collaborative projects. So you are right: in this way, research creates families - both with children and grandchildren!

\section{References}

ANDERSSON, A.-M., MORAN, N., GAARDSVOLL, H., LINNEMANN, D., BJERKVIG, R., LAERUM, OD. and BOCK E. (1991). Characterization of NCAM expression and function in BT4C and BT4Cn glioma cells. Int. J. Cancer47:124-129. 
BIGNER, S.H., BJERKVIG, R. and LAERUM, O.D. (1985). DNA content and chromosomal composition of malignant human gliomas. Neurol. Clinics 3:769784.

BIGNER, S.H., BJERKVIG, R., LAERUM, O.D., MUHLBAIER, L.H. and BIGNER, D.D. (1987). DNA content and chromosomes in permanent cultured cell lines derived from malignant human gliomas. Anal. Quant. Cytol. Histol. 9:435-444.

BJERKNES, R., BJERKVIG, R. and LAERUM, O.D. (1987). Phagocytic capacity of normal and malignant rat glial cells in culture. J. Nat/. Cancer Inst. 78:279-288.

BJERKVIG, R., HØSTMARK, J., PEDERSEN, P.-H. and LAERUM, O.D. (1991a). Tumor spheroids from biopsy specimens. In: Spheroid Culture in Cancer Research. R. Bjerkvig (Ed.). CRC Press, Boca Raton, pp 41-56.

BJERKVIG, R., ENGEBRAATEN, O., LAERUM, O.D., FREDMAN, P., SVENNERHOLM, L., VRIONIS, F.D., WIKSTRAND, C.J. and BIGNER, D.D. (1991b). Anti-GM2 monoclonal antibodies induce necrosis in GM2-rich cultures of a human glioma cell line. Cancer Res. 51:4643-4648.

BJERKVIG, R., LAERUM, O.D. and MELLA, O. (1986) Glioma cell interactions with fetal rat brain aggregates in vitro and with brain tissue in vivo. Cancer Res. 46:4071-4079.

BJERKVIG, R., LAERUM, O.D. and RUCKLIDGE, G.J. (1989). Immunocytochemical characterization of extracellular matrix proteins expressed by cultured glioma cells. Cancer Res. 49: 5424-5428.

BJERKVIG, R., STEINSVÅG, S.K. and LAERUM, O.D. (1986). Reaggregation of fetal rat brain cells in a stationary culture system I: Methodology and cell identification. In Vitro Cell. \& Develop. Biol. 22:180-192.

BJERKVIG, R., TØNNESEN, A., LAERUM, O.D. and BACKLUND, E.-O. (1990). Multicellular tumor spheroids from human gliomas maintained in organ culture. J. Neurosurg. 72:463-475.

EDVARDSEN, K., PEDERSEN, P.-H., BJERKVIG, R., HERMANN, G.G., ZEUTHEN, J., LAERUM, O.D., WALSH, F.S. and BOCK, E. (1994). Transfection of glioma cells with the neural-cell adhesion molecule NCAM: Effect on glioma cell invasion and growth in vivo. Int. J. Cancer 58:116-122.

ENGEBRAATEN, O., BJERKVIG, R., LUND-JOHANSEN, M., WESTER, K., PEDERSEN, P.-H., MØRK, S., BACKLUND, E.-O. and LAERUM, O.D. (1990). Interaction between human brain tumour biopsies and fetal rat brain tissue in vitro. Acta Neuropathol. 81:130-140.

ENGebraAten, O., BJeRKVIG, R., PEDERSEN, P.-H. and LAERUM, O.D. (1993). Effects of EGF, bFGF, NGF and PDGF (bb) on cell proliferative, migratory and invasive capacities of human brain-tumour biopsies in vitro. Int. J. Cancer53:209-214.

ENGEBRÅTEN, O., SCHWACHENWALD, R., VALEN, H., BJERKVIG, R., LAERUM, O.D. and BACKLUND, E.-O. (1992). Effects of high and low single dose irradiation on glioma spheroid invasion into normal rat brain tissue in vitro. Anticancer Res. 12:1501-1506, 1992.

FJELLBIRKELAND, L., BJERKVIG, R., STEINSVÅG, S.K. and LAERUM, O.D. (1996). Nonadhesive stationary organ culture of human bronchial mucosa. $\mathrm{Am}$. J. Respir. Cell Mol. Biol. 15:197-206.

FJELLBIRKELAND, L., BJERKVIG, R. and LAERUM, O.D. (1998a). Non-small-cell lung carcinoma cells invade human bronchial mucosa in vitro. In Vitro Cell. \& Dev. Biol. -Anima/33:333-340.

FJELLBIRKELAND, L., LAERUM, O.D. and BJERKVIG, R. (1998b). Invasiveness by lacZtransfected non-small cell lung cancer cells into human bronchial tissues in vitro. Lung Cancer 21:7-19.

HAUGEN, Å. and LAERUM, O.D. (1978a). Scanning electron microscopy of neoplastic neurogenic rat cell lines in culture. Acta. path. microbiol. scand. Sect. A. 86:101-110.

HAUGEN, A. and LAERUM, O.D. (1978b). Ultrastructure and actin distribution in neoplastic neurogenic cells in culture. Acta. path. microbiol. scand. Sect. A. 86:415-426.

HAUGEN, A. and LAERUM, O.D. (1978c). Surface structure of fetal rat brain cells during neoplastic transformation in cell culture. J. Natl. Cancer Inst. 61:14151422.

HAUGEN; Å. and LAERUM, O.D. (1978d). Induced glial differentiation of fetal rat brain cells in culture: An ultrastructural study. Brain Res. 150:225-238

HAUGEN, A. and LAERUM, O.D. (1979). Transmission electron microscopy of fetal rat brain cells during neoplastic transformation in cell culture. J. Natl. Cancer Inst. 63:455-464
HUMPHREY, P.A., GANGAROSA, L.M., WONG, A.J., ARCHER, G.E., LUNDJOHANSEN, M., BJERKVIG, R., LAERUM, O.D., FRIEDMAN, H.S. and BIGNER D.D. (1991). Deletion-mutant epidermal growth factor reception in human gliomas: Effect of type II mutation on receptor function. Biochem. Biophys. Res. Commun. 178:1413-1420.

LAERUM, O.D., BJERKVIG, R., STEINSVÅG, S.K. and RIDDER, L. de (1984). Invasiveness of primary brain tumors. Cancer Metastasis Rev. 3:223-236.

LAERUM, O.D. and BJERKVIG, R. (1990). Monolayer and three-dimensional culture of rat and human central nervous system: Normal and malignant cells and their interactions. In: Methods in Neurosciences. Vol. 2, Cell Culture. P.M. Conn (Ed.). Academic Press, Inc., London, New York, pp. 210-236.

LAERUM, O.D., HÜLSER, D.F. and RAJEWSKY, M.F. (1976). Electrophysiological properties of ethylnitrosourea-induced, neoplastic neurogenic rat cell lines cultured in vitro and in vivo. Cancer Res. 36:2153-2161.

LAERUM, O.D., MØRK, S., RAJEWSKY, M.F., HANSTEEN, I.L. and HAUGEN, Å. (1983). Heterogeneity and selection of neurogenic rat cells in vivo and in vitro. Anticancer Res. 3:187-194.

LAERUM, O.D., MØRK, S. and RIDDER, L. de (1982). Morphology of malignant rat glioma cells during invasion into chick heart fragments in vitro. In: Tumour Progression and Markers. K. Lapis, A. Jeney and M.R. Price (Eds.). Kugler Publications Amsterdam, pp. 25-31.

LAERUM, O.D., MÖRK, S.J., HAUGEN, Å., BOCK, E., ROSENGREN, L. and HAGLID, K. (1985). Differentiation markers (S-100, GFAP, NSE and D2) in fetal rat brain cells during malignant transformation in cell culture. J. Neuro-Oncology 3:37-146.

LAERUM, O.D., MØRK, S.J. and RIDDER, L. de (1984). The transformation process. Prog. Exp. Tumor Res. 27:17-31.

LAERUM, O.D. and MØRK, S.J. (1998). Mechanisms of altered growth control: invasion and metastasis. In: Russelland Rubinsteins's Pathology of Tumors of the Nervous System, Sixth edition, Vol I., D.D. Bigner, R.E. McLendon, J.M. Bruner (Eds.). Edward Arnold (Publishers) Ltd., London, chapter 4, pp 117-140.

LAERUM, O.D., RAJEWSKY, M.F. and RIDDER, L. de (1982). Malignant transformation of rat neural cells in culture. Ann. N. Y. Acad. Sci. 381:264-273.

LAERUM, O.D., RAJEWSKY, M.F., SCHACHNER, M., STAVROU, D., HAGLID, K.G. and HAUGEN, Å. (1977). Phenotypic properties of neoplastic cell lines developed from fetal rat brain cells in culture after exposure to ethylnitrosourea in vivo. $Z$. Krebsforsch. 89:273-295.

LAERUM, O.D. and RAJEWSKY, M.F. (1975). Neoplastic transformation of fetal rat brain cells in culture after exposure to ethyl-nitrosourea in vivo. J. Natl. Cancer Inst. 55:1177-1186.

LAERUM, O.D. and ROSENBLUM, M.L. (1998). Brain tumor cell invasion: Present knowledge and future prospects. In: Brain Tumor Invasion. Biological, Clinical and Therapeutic Considerations. Mikkelsen, T., Bjerkvig, R., Laerum, O.D. and Rosenblum, M.L. (Eds). John Wiley \& Sons, Inc, New York, pp 449-455.

LAERUM, O.D., STEINSVÅG, S. and BJERKVIG, R. (1985). Cell and tissue culture of the central nervous system: Recent developments and current applications. Acta. Neurol. Scand. 72:529-549.

LAERUM, O.D. (1997). Local spread of malignant neuroepithelial tumors. Acta Neurochir. (Wien) 139:515-522.

LAERUM, O.D., NYGAARD, S.J.T., STEINE, S., MØRK, S.J., ENGEBRAATEN, O., PERAUD, A., KLEIHUES, P. and OHGAKI, H. (2001). Invasiveness in vitro and biological markers in human primary glioblastomas. J. Neurooncol. 54:1-8.

LUND-JOHANSEN, M., BJERKVIG, R., HUMPHREY, P.A., BIGNER, S.H., BIGNER, D.D. and LAERUM, O.D. (1990). Effect of epidermal growth factor on glioma cell growth, migration and invasion in vitro. Cancer Res. 50:60396044.

LUND-JOHANSEN, M., ENGEBRAATEN, O., BJERKVIG, R. and LAERUM, O.D. (1992). Invasive glioma cell in tissue culture. Anticancer Res. 10:1135-1152.

LUND-JOHANSEN, M., FORSBERG, K., BJERKVIG, R. and LAERUM, O. D. (1992). Effects of growth factors on a human glioma cell line during invasion into rat brain aggregates in culture. Acta Neuropathol. 84:190-197.

MARIENHAGEN, K., PEDERSEN, P.-H., TERZIS, A.J.A., LAERUM, O.D. and BJERKVIG, R. (1994). Interactions between fetal rat brain cells and mature brain tissue in vivo and in vitro. Neuropathol. Appl. Neurobiol. 20:130-143.

MELLA, O., BJERKVIG, R., SCHEM, B.C., DAHL, O. and LAERUM, O.D. (1990). A cerebral glioma model for experimental therapy and in vivo invasion studies in syngeneic BD IX rats. J. Neurooncol. 9:93-104. 
MIKKELSEN, T., BJERKVIG, R., LAERUM, O.D. and ROSENBLUM, M.L. (Eds) (1998). Brain tumor invasion. Biological, clinical and therapeutic considerations. John Wiley \& Sons Inc, New York.

MØRK, S.J., LAERUM, O.D. and RIDDER, L., de (1983). Transmission electron microscopy of malignant neurogenic rat cells during invasion into embryonic chick heart fragments in vivo. Anticancer Res. 3:373-384.

MØRK, S., LAERUM, O.D. and RIDDER, L. de (1984). Invasiveness of tumours of the central nervous system. In: Invasion - Experimental and Clinical Implications. M.M. Mareel and K.C. Calman (Eds). Oxford University Press, Oxford, New York, Tokyo, pp. 79-125.

MØRK, S., RIDDER, L. de and LAERUM, O.D. (1982). Invasive pattern and phenotypic properties of malignant neurogenic rat cells in vivo and in vitro. Anticancer Res. 2:1-10.

NESS, G.O., PEDERSEN, P.-H., BJERKVIG, R., LAERUM, O.D. and LILLEHAUG, J.R. (1994). Three-dimensional growth of glial cell lines affects growth factor and growth factor receptor mRNA levels. Exp. Cell Res. 214:433-436.

NYGAARD, S.J.T., HAUGLAND, H.K., KRISTOFFERSEN, E.K., LUNDJOHANSEN, M., LAERUM, O.D., TYSNES, O.-B. (1998). Expression of annexin II in glioma cell lines and in brain tumor biopsies. J. Neurooncol. 38:11-18.

NYGAARD, S.J.T., HAUGLAND, H.K., LAERUM, O.D., LUND-JOHANSEN, M., BJERKVIG, R. and TYSNES, O.-B. (1998). Dynamic determination of human glioma invasion in vitro. J. Neurosurg. 89:441-447.

NYGAARD, S.J.T., LAERUM, O.D. and TYSNES, O.-B. (1994). Heterogeneous effects of bradykinin and A23187 on glioma growth, migration and invasion. Int. J. Oncol. 5:69-75.

PEDERSEN, P.-H., NESS, G.O., ENGEBRAATEN, O., BJERKVIG, R., LILLEHAUG, J.R. and LAERUM, O.D. (1994). Heterogeneous response to the growth factors [EGF, PDGF (bb), TGF-a, bFGF, IL-2] on glioma spheroid growth, migration and invasion. Int. J. Cancer56:255-261, 1994.
PEDERSEN, P.-H., RUCKLIDGE, G.J., MØRK, S.J., TERZIS, A.J.A., ENGEBRAATEN, O., LUND-JOHANSEN, M., BACKLUND, E.-O., LAERUM, O.D. and BJERKVIG, R. (1994). Leptomeningeal tissue: a barrier against brain tumor cell invasion. $J$. Natl. Cancer Inst. 86:1593-1599.

RIDDER, L. de, LAERUM, O.D., MØRK, S.J. and BIGNER, D.D. (1987). Invasiveness of human glioma cell lines in vitro: Relation to tumorigenicity in athymic mice. Acta Neuropathol. (Berl.) 72:207-213.

RIDDER, L. de and LAERUM, O.D. (1981a). Invasion of rat neurogenic cell lines in embryonic chick heart fragments in vitro. J. Natt. Cancer Inst. 66:723-728.

RIDDER, L. de and LAERUM, O.D. (1981b). Malignancy of neurogenic cells characterized by their invasiveness in vitro. Arch. Geschwulstforsch. 51:28-33.

STEINSVÅG, S.K. (1985). Interaction between glioma cells and normal brain tissue in organ culture studied by scanning electron microscopy. Invasion Metastasis 5 : 255-269.

STEINSVÅG, S.K. and LAERUM, O.D. (1985a). Transmission electron microscopy of cocultures between normal rat brain tissue and rat glioma cells. Anticancer Res. 5:137-146.

STEINSVÅG, S.K. and LAERUM, O.D. (1985b). Fetal rat brain hemisphere tissue in nonadherent stationary organ culture. Experientia 41:1517-1524.

STEINSVÅG, S.K., LAERUM, O.D. and BJERKVIG, R. (1985). Interaction between rat glioma cells and normal rat brain tissue in organ culture. J. Natt. Cancer Inst. 74:1095-1104.

TERZIS, A.J.A., ARNOLD, H., LAERUM, O.D. and BJERKVIG, R. (1994). Interaction between human medulloblastomas and foetal rat brain aggregates in vitro. Acta Neurochir. 126:11-16.

TONN, J.-C., HAUGLAND, H.K., SARASTE, J., ROOSEN, K. and LAERUM, O.D. (1995). Differential effects of vincristine and phenytoin on the proliferation migration, and invasion of human glioma cell lines. J. Neurosurg. 82:1035-1043.

TYSNES, O.-B. and LAERUM, O.D. (1993). Differential effects of 12-O-tetradecanoyl13-phorbol acetate (TPA) on growth, migration and invasion of a human glioma cell line. Anticancer Res. 13:1325-1330. 